\title{
Cryosphere hazards in Ladakh: the 2014 Gya glacial lake outburst flood and its implications for risk assessment
}

\author{
Susanne Schmidt ${ }^{1} \cdot$ Marcus Nüsser $^{1,2}$ (ID) $\cdot$ Ravi Baghel $^{1} \cdot$ Juliane Dame $^{1,2}$
}

Received: 7 March 2020 / Accepted: 24 August 2020 / Published online: 5 September 2020

(c) The Author(s) 2020

\begin{abstract}
This article attempts to reconstruct the causes and consequences of the 2014 glacial lake outburst flood (GLOF) event in Gya, Ladakh. We analyse the evolution of the Gya glacial lake using a high temporal and high spatial resolution remote sensing approach. In order to frame the case study in a larger picture, we produce a comprehensive inventory of glacial lakes for the entire Trans-Himalayan region of Ladakh. Changes in the extent and number of glacial lakes have been detected for the years 1969, 1993, 2000/02 and 2018 in order to assess the potential risk of future GLOFs in the region. The remote sensing approach was supported by field surveys between 2014 and 2019. The case study of the Gya GLOF illustrates the problem of potentially hazardous lakes being overlooked in inventories. The broader analysis of the Ladakh region and in-depth analysis of one GLOF lead us to propose an integrated approach for detecting undocumented GLOFs. This article demonstrates the necessity for using multiple methods to ensure robustness of risk assessment. The improved understanding can lead to a more accurate evaluation of exposure to cryosphere hazards and identification of alternative mechanisms and spatial patterns of GLOFs in the Himalaya.
\end{abstract}

Keywords Cryosphere hazards · GLOF · Tunneling of ice-cored moraines · Ice-covered lakes $\cdot$ Ladakh $\cdot$ India

\section{Introduction}

Cryosphere dynamics and cryosphere-related hazards are a vital component of and threat for land use development in the semi-arid Trans-Himalayan region of Ladakh. The observed and projected glacier decrease in the extended Himalayan region (Bolch et al. 2019) and specifically in Ladakh (Schmidt and Nüsser 2017) will affect livelihood security, both in the mountains and in the lowlands in the long run (Hock et al. 2019; Huss and Hock 2018; Immerzeel et al. 2010; Nüsser et al. 2019). In the short term, glacial lake outburst floods (GLOFs) are major cryosphere hazards and a potential risk for local communities

Marcus Nüsser

marcus.nuesser@uni-heidelberg.de

South Asia Institute, Department of Geography, Heidelberg University, Heidelberg, Germany

2 Heidelberg Centre for the Environment (HCE), Heidelberg University, Heidelberg, Germany 
as lakes are formed and grow due to deglaciation (Carey et al. 2017; Carrivick and Tweed 2016; Emmer and Vilímek 2013; Emmer 2018; Rasul and Molden 2019).

On 6 August 2014, a glacial lake outburst flood (GLOF) hit the village of Gya (33 $39^{\prime}$ $\mathrm{N}, 77^{\circ} 44^{\prime} \mathrm{E}$ ) in Ladakh. GLOF events are not a new phenomenon in the upper Indus basin: a number of such events have been reported from the Karakoram and Western Himalaya dating back to the nineteenth century (Hewitt 1982; Hewitt and Liu 2010; Iturrizaga 2019). Large and recurrent GLOF events happened in the Shyok and Nubra valley, where the river was blocked by a glacier several times during the nineteenth century, followed by destructive outburst floods (Bhambri et al. 2019, 2020; Cunningham 1854; Sheikh 2015; Sinclair 1929).

However, only after the GLOF of Dig Tsho, a glacial lake in the Khumbu region of Nepal in 1985 (Vuichard and Zimmermann 1987) was there a rise of scientific interest in glacial lake dynamics and potential risk of outburst floods in the Himalaya. Since then, various studies have analysed GLOF events (Allen et al. 2016b; Ashraf et al. 2012; Nie et al. 2018) and their potential risk (Allen et al. 2016a; Sharma et al. 2018; Wang et al. 2012) in different parts of the Hindu Kush-Karakoram-Himalaya (HKH). Contrary to the findings of Richardson and Reynolds (2000) that GLOF events have become more frequent, Komori et al. (2012) and Veh et al. (2019) could not detect an increase in GLOF events in the central and eastern Himalaya over the last few decades. However, a global analysis of GLOFs suggests that they demonstrate a lagged response to climate change and they are likely to become more frequent over the next decades, lasting into the twenty-second century (Harrison et al. 2018). Although it is difficult to give precise figures due to differing data sets and methodology, all studies show an increase in the number and area of glacial lakes in the HKH (Bolch et al. 2019; Ives et al. 2010; Nie et al. 2017; Zhang et al. 2015). The largest absolute glacial lake growth was observed in the central and eastern Himalaya (Bajracharya and Mool 2009; Gardelle et al. 2011; Haritashya et al. 2018).

Only a few destructive GLOFs have been reported from the Trans-Himalayan region of Ladakh during recent decades (Ikeda et al. 2016; Morup 2014; Narama et al. 2012; Tabassum and Kanth 2013). One GLOF was described from Nyoma in the Changthang area in eastern Ladakh in 1971, which caused 13 to 16 fatalities. Another GLOF happened in Domkhar in 2003, which destroyed farmland and infrastructure (Ikeda et al. 2016). The most recent reported GLOF is the 2014 Gya flood (Dolma 2014). This paper attempts to reconstruct the causes and consequences of the GLOF event at Gya village and to analyse the evolution of the glacier lake using a high temporal and high spatial remote sensing approach with data from 1969 to 2019. For the entire region of Ladakh, a multi-temporal and multi-scale remote sensing approach (Corona, Landsat, Sentinel) was conducted to investigate changes of glacial lakes and GLOF events. Based on this new inventory of glacier lakes in Ladakh, probable former GLOF events and the potential risk of future GLOFs are analysed. Identification of unreported or undocumented GLOFs can lead to a more accurate assessment of exposure and risk of cryosphere hazards. The remote sensing approach was supported by field surveys between 2014 and 2019 .

\section{Study area}

The Trans-Himalayan region of Ladakh is situated between the Greater Himalayan Range to the south and the Karakoram Range to the north at an altitude of over $3000 \mathrm{~m}$ a.s.1., with surrounding mountain ranges exceeding altitudes of $5500 \mathrm{~m}$ a.s.l. Rain shadow effects 
result in steep hygric gradients of decreasing precipitation from west to east and south to north (Hussain Dahri et al. 2016). Despite the general cold-arid conditions, occasional torrential rainstorms may cause floods, such as the extreme cloudburst in August 2010 (Thayyen et al. 2013; Ziegler et al. 2016). The specific combination of topography and climate contributes to the small size and high altitude of glaciers, almost all of which terminate above $5200 \mathrm{~m}$ a.s.l. and are smaller than $0.75 \mathrm{~km}^{2}$. Glaciated area reduction ranges from 0.2 to $0.9 \%$ year $^{-1}$ for the period between 1969 and 2016, with high variability across different watersheds (Schmidt and Nüsser 2017). Meltwater from these small glaciers and permafrost thaw (Ali et al. 2018) determines the potential for habitation and irrigated crop cultivation (Nüsser et al. 2012), only found along the Indus and Shyok rivers, on alluvial fans, or tributary valleys between $2200 \mathrm{~m}$ a.s.l. and $4370 \mathrm{~m}$ a.s.l. (Fig. 1). The region is sparsely populated and has a total of about 274,300 inhabitants (Leh and Kargil districts, since 2019 administered as a Union Territory), with the registered population expanding by 1.5\% annually between 2001 and 2011 (Census of India 2011).

Gya, the case study village, is located at an altitude of $4010 \mathrm{~m}$ a.s.1. on the eastern slope of the Kang Yatze massif, close to the Taglang La (5328 m a.s.1.) on the main road connecting Leh and Manali. At the end of the nineteenth century, the village together with neighbouring hamlets consisted of 40 houses and a monastery and served as a halting place with grazing grounds for animals along the historical trading route (Gazetteer of Kashmir and Ladák 1890). The old settlement is located along a small ridge between a palaeo-fluvial terrace, which is used for agriculture, and the current channel of Gya rivulet (Fig. 2). A second small kernel is located above the irrigated area on the southern side of the rivulet, which divides the cultivated area into a northern and southern part. Both built-up areas have been constructed on flood-protected places. The village has grown to more than 700 inhabitants (Government of Jammu \& Kashmir 2011-2012) dispersing into the cultivated area of 89 ha (Fig. 3). Only a few houses were built in the vicinity of the stream. The upper catchment of the 16-km-long Gya valley is characterized by glaciers and perennial snow fields above $5400 \mathrm{~m}$ a.s.1., which cover an area of about $2.9 \mathrm{~km}^{2}$ and feed the irrigated fields of the village. The Gya glacier affected by the proglacial lake was identified as receding very fast compared to neighbouring glaciers of the Kang Yatze massif (Schmidt and Nüsser 2012).

\section{Data and methods}

\subsection{Lake inventory of the Trans-Himalaya}

Periglacial and glacial lakes have been mapped on Corona images from 1969, Landsat imagery from 1993, 2000/2002, and Sentinel 2 data from 2018 (Table 1) in order to analyse the evolution of lakes and to assess future risk. Temporally adjoining images were added to fill data gaps caused by cloud coverage.

The delineation of lakes in radiometric calibrated and co-registered Sentinel and Landsat images was carried out using a standardized semi-automatic approach based on a Normalized Difference Water Index (NDWI) according to the formula (NIR - B)/ $(\mathrm{NIR}+\mathrm{B})$. The usage of near-infrared and blue band representing maximum and minimum reflectance for water gives good discrimination between ice and snow (Allen et al. 2016b; Bolch et al. 2012; Huggel et al. 2002; Worni et al. 2013). Misclassified pixels were removed using slope angle and shadow masks. Water bodies below $4000 \mathrm{~m}$ a.s.l. 


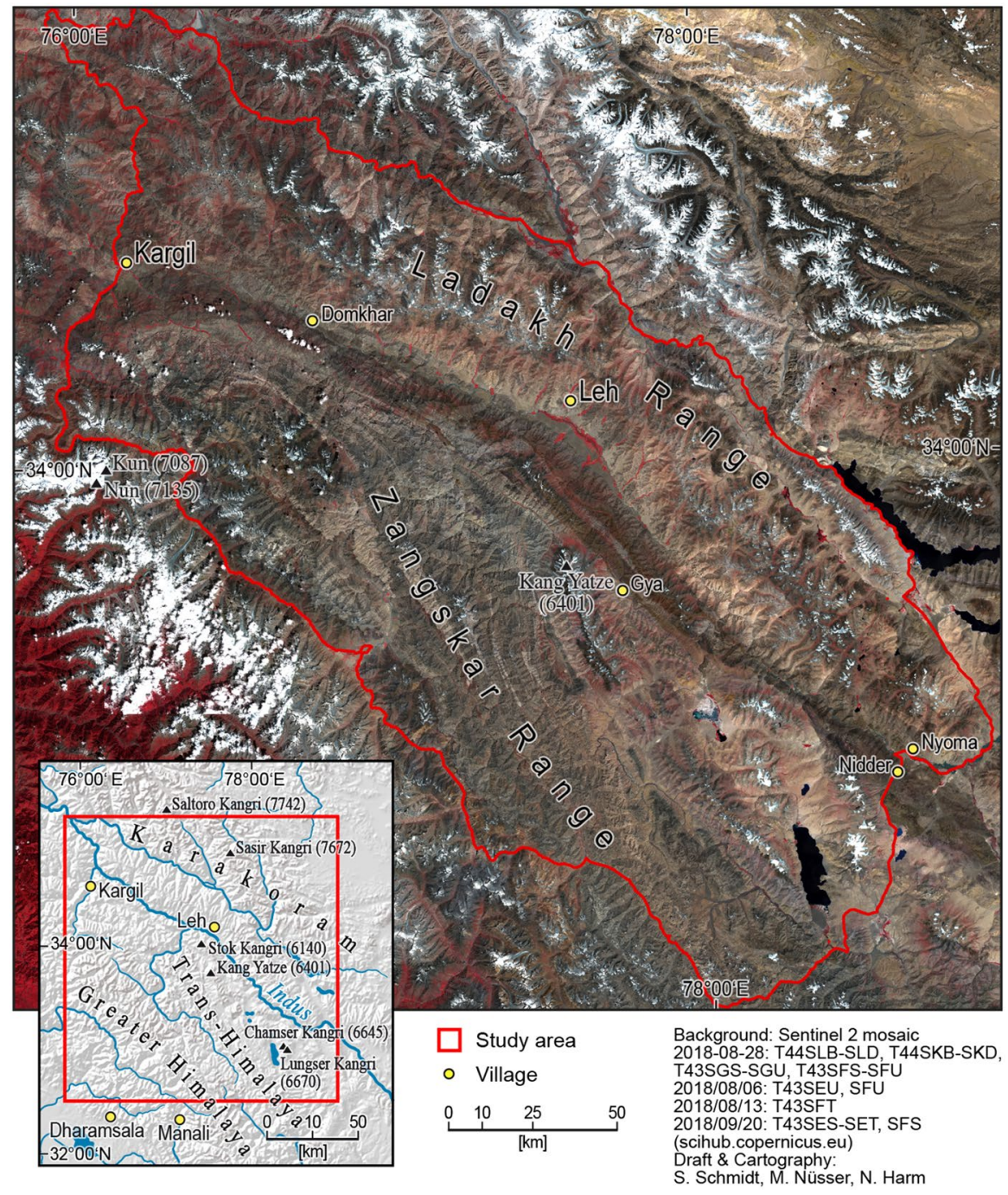

Fig. 1 Study area: the Trans-Himalayan region of Ladakh

were deleted because glacial lakes do not exist at these altitudes under given climatic and environmental conditions. The remaining classified lake pixels were converted to vector data for automatic calculation of lake size. All lakes smaller than $9000 \mathrm{~m}^{2}$ were removed, because their change detection was regarded as too uncertain given the spatial resolution of Landsat images used for the years 1993 and 2002. Uncertainty in glacial lake area was estimated to be half a pixel (Kamp et al. 2011). In the final pre-processing step, all lakes were controlled by visual interpretation, remaining misclassified water bodies were removed, snow-covered and frozen lakes were added, and some lakes, which were partly ice-covered, rich in sediment load or located in shadow positions, were corrected. On orthorectified panchromatic Corona images, the lakes were digitized on screen in a geographical information system (ArcGIS 10.6) based on detailed visual 


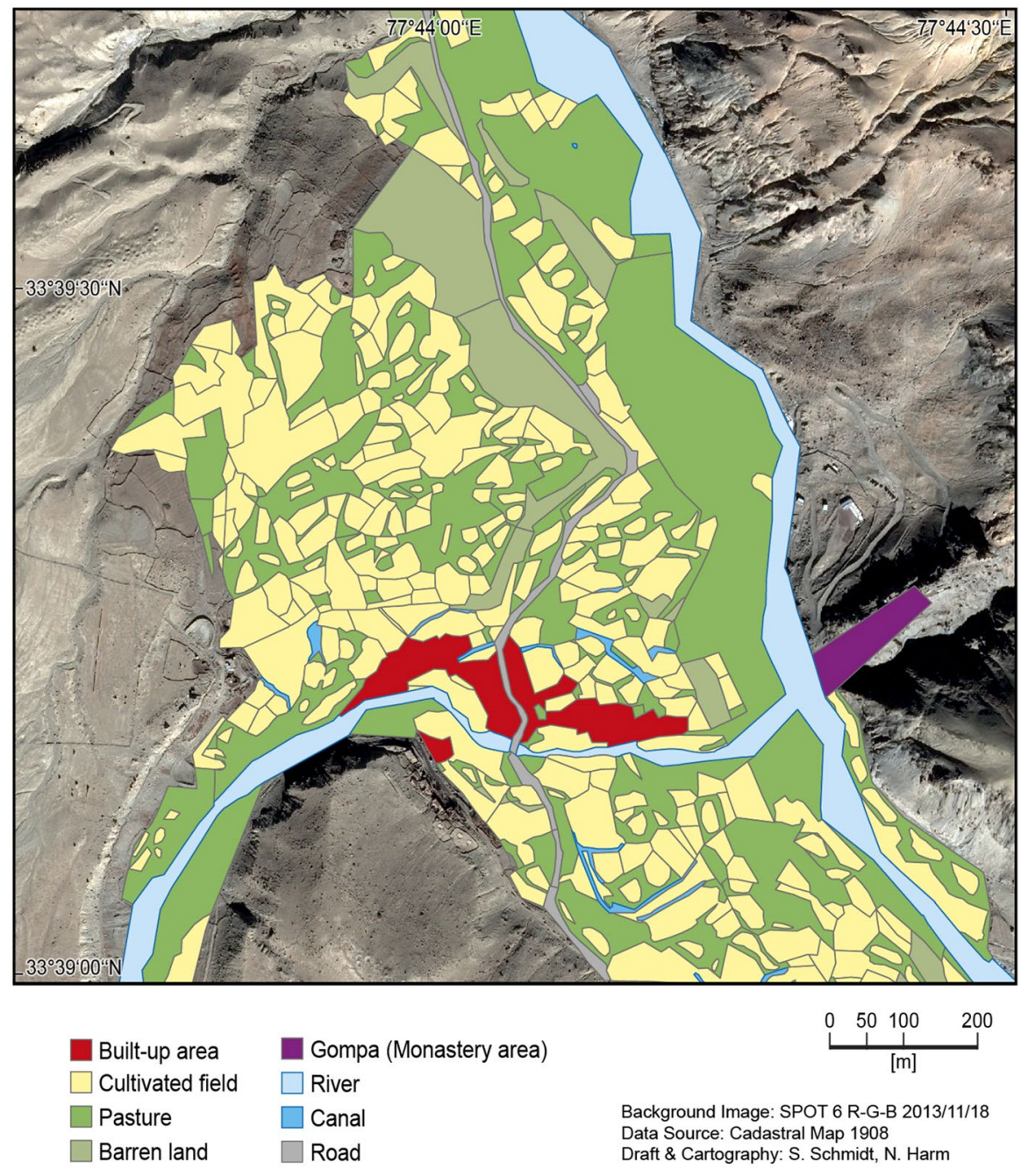

Fig. 2 Land use pattern of Gya in 1908

image interpretation. Additionally, lakes smaller than $9000 \mathrm{~m}^{2}$, which can be detected on at least one of the other three time periods, were digitized in order to investigate since when these lakes have existed or if they have ever completely discharged. Finally, each lake was categorized as proglacial lake (PG), supraglacial lake, lake in a recent moraine (RM), lakes in Pleistocene moraine, cirque lake and landslide dammed lake. Change detection analyses were conducted for three distinct time spans: 1969-1993, 1993-2000/02 and 2000/02-2018.

To estimate glacial lake volume, several empirical formulae exist (Cook and Quincey 2015; Muñoz et al. 2020). For this study, the water volume for all time spans was calculated according to the widely accepted empirical formula by Huggel et al. (2002):

$$
V: 0.104 * A^{1.42}
$$




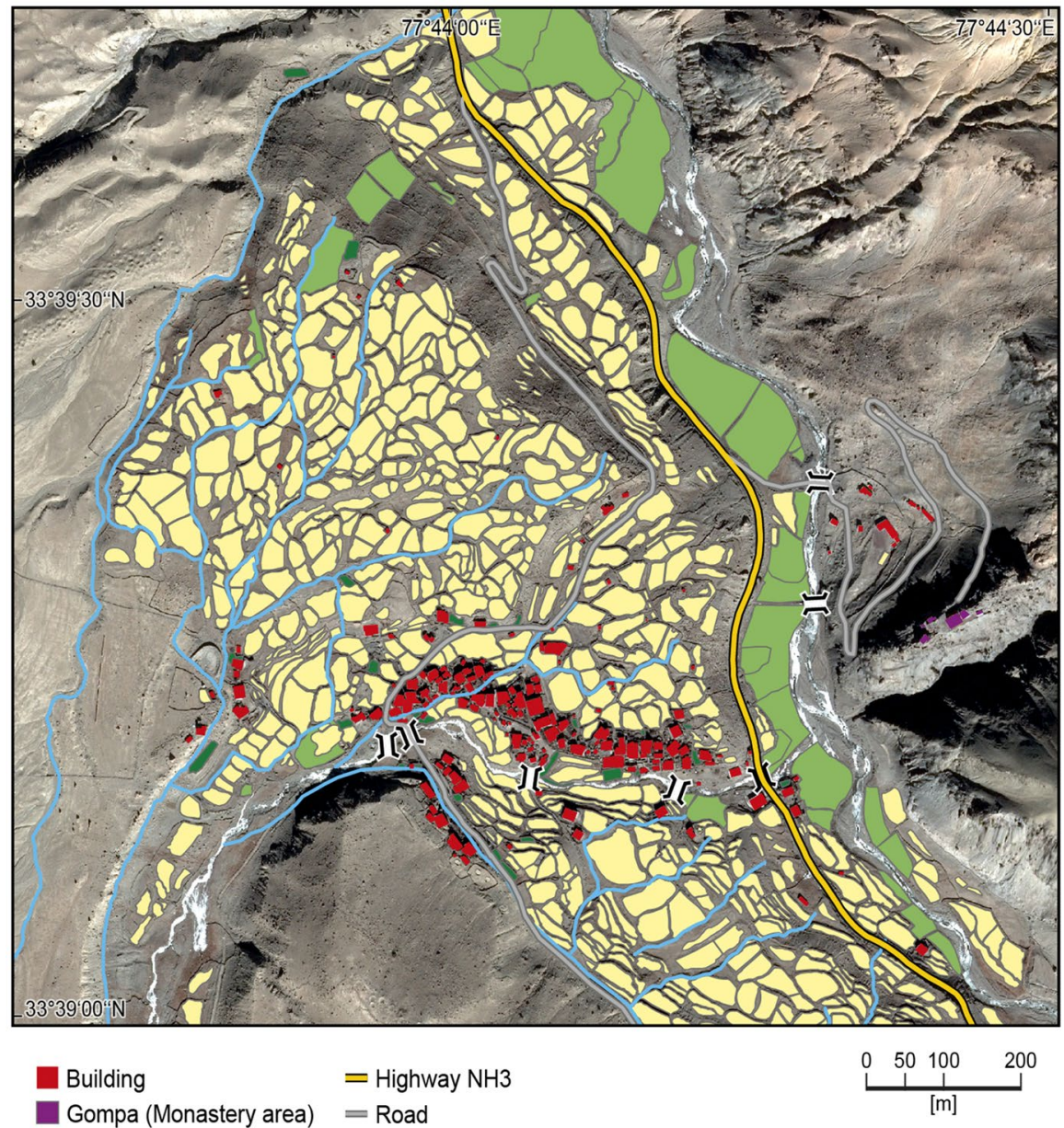

Background Image: SPOT 6 R-G-B 2013/11/18 Data Source: SPOT 6 2013/11/18

Draft \& Cartography: S. Schmidt, N. Harm

$\square$ Pasture

$\stackrel{\sim}{\sim}$ Bridge

- Canal

Fig. 3 Land use pattern of Gya in 2013

with V: volume, A: lake area.

The time series analyses of Gya indicated that volume changes up to $100,000 \mathrm{~m}^{3}$ are within the seasonal range; a threshold of more than $200,000 \mathrm{~m}^{3}$ was used to detect potential GLOFs.

\subsection{Gya lake and the 2014 Gya GLOF event}

For the in-depth study of the GLOF event in Gya on 6 August 2014, high spatial resolution and multi-spectral images were used to analyse lake evolution, lake level changes before and after the event, changes of the moraine for further risk assessment, and size and damages of the flood. 
Table 1 Remote sensing imagery used for glacial and periglacial lake inventory and monitoring

\begin{tabular}{|c|c|c|c|}
\hline Satellite & Acquisition date & Path/row & $\begin{array}{l}\text { Spatial } \\
\text { resolution } \\
(\mathrm{m})\end{array}$ \\
\hline Corona & $1969 / 07 / 30$ & $\begin{array}{l}\text { DS1107- } \\
\text { 1104DA011 } \\
\text { to DS1107- } \\
\text { 1104DA025 } \\
\text { DS1115- } \\
\text { 2282DA49 } \\
\text { to DS1115- } \\
\text { 2282DA57 }\end{array}$ & 2 \\
\hline Landsat 5 & $\begin{array}{l}1993 / 06 / 07 ; 1993 / 07 / 25 \\
1993 / 09 / 02 \\
1993 / 08 / 17 \\
1993 / 07 / 07 \\
1993 / 06 / 05 ; 1994 / 10 / 30\end{array}$ & $\begin{array}{l}146 / 37 \\
147 / 36-37 \\
147 / 37 \\
148 / 37 \\
148 / 36\end{array}$ & 30 \\
\hline Landsat 7 & $\begin{array}{l}2002 / 08 / 02 \\
2000 / 08 / 27 \\
2000 / 10 / 08\end{array}$ & $\begin{array}{l}147 / 36-37 \\
148 / 36-37 \\
146 / 37\end{array}$ & 30 \\
\hline Sentinel 2 & $\begin{array}{l}\text { 2018/08/28 } \\
\text { 2018/07/07; 2018/08/31 }\end{array}$ & $\begin{array}{l}\text { EM-UTM43N } \\
\text { WM-UTM-43 N }\end{array}$ & 10 \\
\hline
\end{tabular}

\subsubsection{Changes in the proglacial lake}

In order to analyse the lake evolution, multi-temporal and multi-scale remote sensing imagery from different satellites preferably taken in summer or autumn were used to generate a long time series. Starting with Corona images from 1969, available cloud- and snow-free Landsat imagery from 1989 to 2014 and Sentinel 2, RapidEye and PlanetScope data from 2014 to 2019 were used (Table 2). Due to the growing availability of free and open satellite imagery, the temporal and spatial resolution has improved, thereby reducing uncertainty.

The outline of the proglacial lake was digitized manually on-screen on all selected images. The semi-automatic approach, which was used for the lake detection of the Trans-Himalaya, was not possible, due to the frequent ice coverage of this lake. For error estimation using the root-mean-square error, we used half a pixel size as a buffer (Kamp et al. 2011).

\subsubsection{Investigation of the 2014 Gya GLOF event}

The 2014 Gya GLOF was investigated using high spatial resolution images taken before and after the event. The Pléiades image, taken on the morning of 6 August 2014, allowed the detection of the maximum lake level a few hours before the GLOF hit Gya village.

To estimate lake level changes, the altitude of the lake before and after the event has been calculated. Therefore, on stable ground-excluding the glaciated area-vertices of the digitized outlines of the lake from 6 August 2014 and 13 October 2014 have been used to derive the elevation from TanDEM-X data, processed and delivered by German Aerospace Center (DLR) from interferometry data taken between 2011 and 2013. The calculated difference between the averaged elevations of both time steps represents lake level fluctuations. This height difference-multiplied by the size of the lake area-was used to estimate the water discharge by the GLOF. Additionally, the released water volume was 


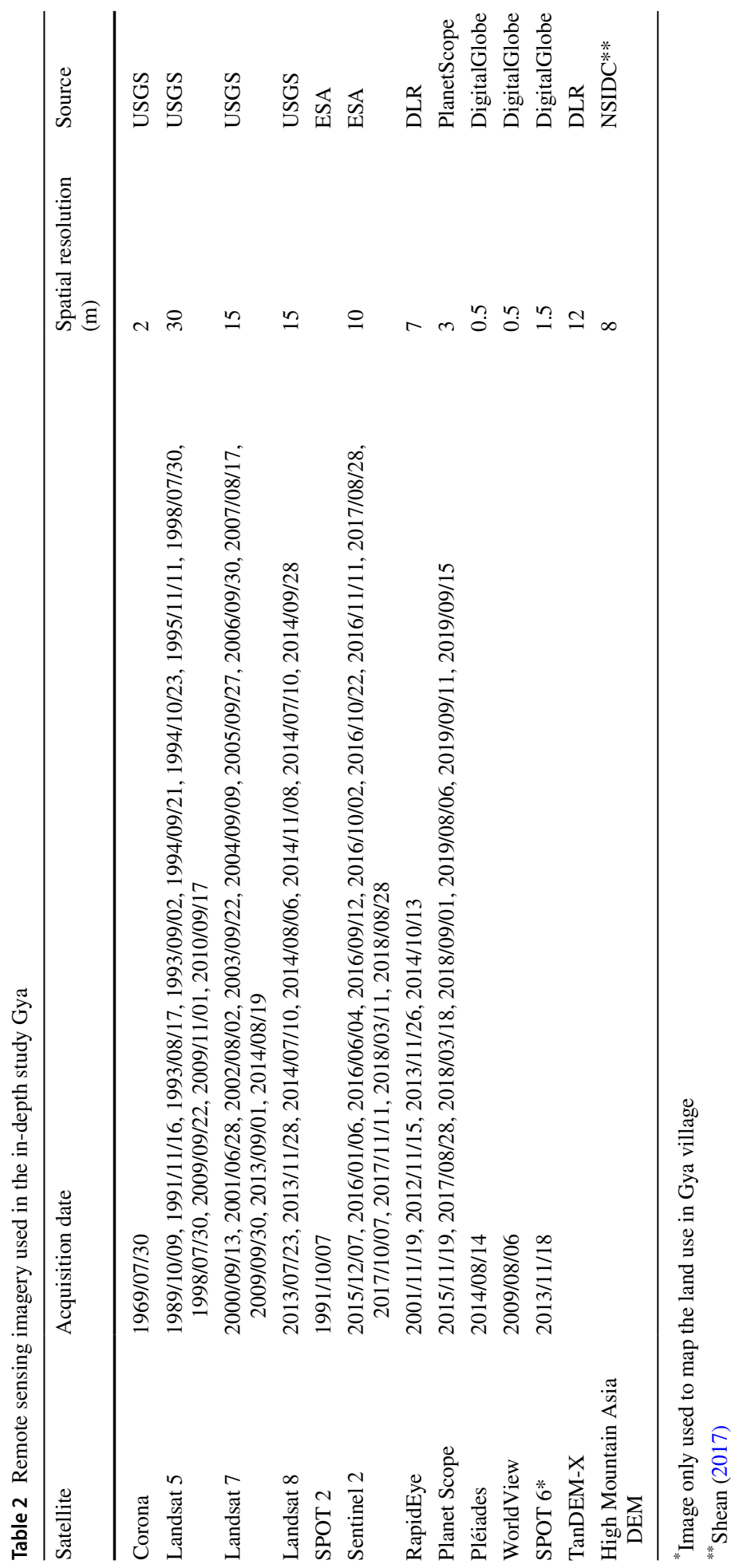


derived from the difference between the estimated lake volume before and after the GLOF event according to the above-mentioned empirical formula by Huggel et al. (2002). The same approach was used to estimate the released water volume in 2019. We estimated the peak discharge $\left(Q_{\max }\right)$ with a water volume $V\left(\mathrm{~km}^{3}\right)$ by the empirical formula by Walder and Costa (1996) for tunnel events:

$$
Q_{\max }: 46 V^{0.66}
$$

The flooded area was reconstructed conducting a change detection analyses of two radiometric calibrated RapidEye images (2013/11/26 and 2014/10/13) representing the situation before and after the GLOF event. For this purpose, an unsupervised classification of the combined Normalized Difference Vegetation Index (NDVI) derived from both images was conducted within a distance of $300 \mathrm{~m}$ to the stream. Ten classes were separated and later merged to differentiate flooded and non-flooded areas. The classified flooded area was corrected by visual interpretation. The flood map was used as a mask to quantify the damages in the village, for which the fields, houses and infrastructure were mapped on an orthorectified SPOT-6 image taken on 18 November 2013.

During the field survey in September and October 2014, the proglacial lake was prospected in order to reconstruct the GLOF event, to map the extent of the flood and to assess the potential for further GLOF events. Furthermore, the flooded area and damages in the village were mapped. Semi-structured interviews were conducted with villagers in order to get information on the 2014 GLOF and former floods. Further field visits in 2015 and 2017 only in the village environs and a final survey in August 2019 were used to inspect the situation at the proglacial lake and recent reconstruction in the village.

\section{Results}

The results are divided into two sections, the first on the glacial lake inventory for the entire Ladakh region and the second on the specific case of the Gya GLOF of 2014.

\subsection{Glacial lakes in the Trans-Himalaya of Ladakh}

A total of 192 glacial lakes cover an area of $5.93 \pm 0.70 \mathrm{~km}^{2}$ with an estimated water volume of about $61.11 \pm 8.5$ million $\mathrm{m}^{3}$, including 127 proglacial (PG) and 9 supraglacial lakes and 56 lakes located on recent moraines (RM) in 2018 (Fig. 4). Apart from these, 30 lakes are located in front of recent moraines (combined area: $1.53 \pm 0.14 \mathrm{~km}^{2}$ ) and 14 lakes in cirques (combined area: $0.47 \pm 0.04 \mathrm{~km}^{2}$ ). Corresponding to the location of glaciers, the altitude of glacial lakes increases from west to east from below $4900 \mathrm{~m}$ a.s.l. to above $5500 \mathrm{~m}$ a.s.l. The total number of lakes is higher in the western part compared to the east and higher along the Ladakh range compared to the Zanskar range. Furthermore, in the western Ladakh range the highest amount of lakes in pleistocene moraines can be detected (in total 129 lakes with an area of $6.83 \pm 0.55 \mathrm{~km}^{2}$ ), which can be dangerous in the context of cascading flood events. In 2018, most glacial lakes were smaller than $50,000 \mathrm{~m}^{2}$ (equivalent to $490,000 \mathrm{~m}^{3}$ ) with only 10 larger than $100,000 \mathrm{~m}^{2}$ (equal to approximately 1.3 million $\mathrm{m}^{3}$, Fig. 4). The area of the two largest glacial lakes is about $245,000 \mathrm{~m}^{2}$ (equal to approximately 4.7 million $\mathrm{m}^{3}$ ); one of them is located in eastern Ladakh, $24 \mathrm{~km}$ to the south of Pangong Lake, and the second one is located in the western part of the study area, close to the confluence of Shyok and Indus river. 


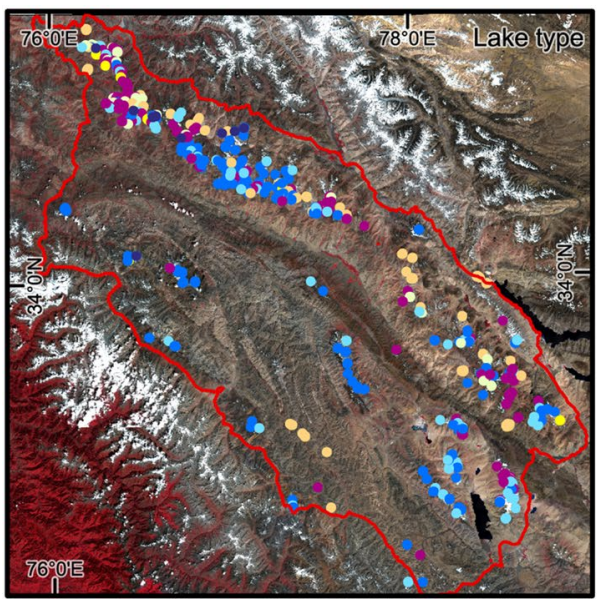

Lake type

- Proglacial lake

- Supraglacial lake

- Recent moraine

- Pleistocene moraine

Landslide or talus cone

dammed lake

In front of moraine

Cirque lake

Study area

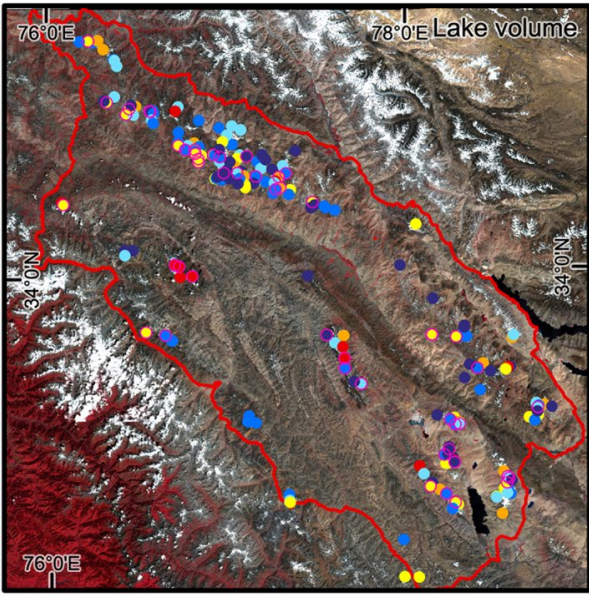

Lake area [km²]

- $<0.009$

- $0.009-<0.025$

$0.025-<0.5$

$0.5-<0.1$

- $0.1-<0.15$

$-\geq 0.15$

- Ice-covered lake

$\square$ Study area

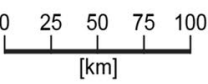

Background: Sentinel 2 mosaic 2018-08-28: T44SLB-SLD,

T44SKB-SKD, T43SGS-SGU,

T43SFS-SFU,

2018-08-06: T43SEU, SFU

2018-08-13: T43SFT

2018-09-20: T43SES-SET, SFS

(scihub.copernicus.eu)

Draft \& Cartography:

S. Schmidt, N. Harm

Fig. 4 Inventory of glacial and periglacial lakes in the Trans-Himalayan region of Ladakh

The number and size of PG and RM lakes have increased over time. On the 1969 Corona images, at least 73 glacial lakes larger than $9000 \mathrm{~m}^{2}$ are already detectable. An additional 42 glacial lakes smaller than $9000 \mathrm{~m}^{2}$ have been taken into consideration. As the coverage of Corona data does not include the entire study area, detailed information on 44 glacial lakes detected in later images is not available for 1969. However, in 1993, ten of the undetectable lakes did not yet exist and only two were larger than $100,000 \mathrm{~m}^{2}$.

The change detection analyses indicated that 22 glacial lakes disappeared (decrease by more than 90\%) between 1969 and 2018: four between 1969 and 1993, nine between 1993 and 2002, and nine from 2002 to 2018. Nine lakes can be detected which released more than $200,000 \mathrm{~m}^{3}$ of water within each period; only two of them completely disappeared between 2002 and 2018. From 1969 to 1993 and 1993 to 2002, most of these lakes were located in the sparsely populated Changthang region in eastern Ladakh (Fig. 5).

The number of lakes with a water volume increase of more than $200,000 \mathrm{~m}^{3}$ has doubled from 14 lakes in the period between 1993 and 2002 to 29 between 2002 and 2018. 
(Only one lake, which is not covered by Corona images, was larger than $200,000 \mathrm{~m}^{3}$ in 1993.) The time series also shows that some of the former released lakes were refilled in the aftermath, such as in the Changthang area and Zanskar range. Many expanding lakes can be found in the western part of the Ladakh range, where the majority of habitations are located.

\subsection{Case study of Gya}

\subsubsection{Evolution of the proglacial lake}

The proglacial Gya lake has developed in front of a cirque glacier at an altitude of $5400 \mathrm{~m}$ a.s.l. (Fig. 6). Glacier retreat and corresponding lake expansion of about $430 \mathrm{~m}$ can be detected for the period between 1969 and 2019. The year of initial lake formation remains unclear. Surrounded by steep slopes, this lake was largely unknown due to its location behind a 400-m-wide and 100-m-high moraine. Only a few aged shepherds, who had to look after their yaks on the high pasture in their younger days, had knowledge of its existence (own interviews). The terminal moraine with a small thermokarst hollow, which was water-filled $\left(100 \mathrm{~m}^{2}\right)$ in August 2014 , is cut by a channel, connected with the proglacial lake by a 6-m-deep depression. The freeboard amounts to about $10 \mathrm{~m}$; thus, the lake discharge occurs subsurface through the moraine and water only reappears at the surface at an altitude of $5300 \mathrm{~m}$ a.s.1.

The time series analyses (Fig. 7) show that the proglacial lake is regularly ice-covered even in summer and has expanded continuously from $0.03 \pm 0.002 \mathrm{~km}^{2}$ (with an estimated water volume of $260,900 \pm 17,900 \mathrm{~m}^{3}$ ) in July 1969 to $0.12 \pm 0.003 \mathrm{~km}^{2}$ (estimated water volume: $1,648,050 \pm 67,800 \mathrm{~m}^{3}$ ) in August 2019. Since 2005, a rapid increase in the lake area can be detected, which has almost doubled from $0.06 \pm 0.007 \mathrm{~km}^{2}$ to $0.12 \pm 0.003$ $\mathrm{km}^{2}$ over the past 15 years. In 2014, a drastic short-term lake level rise occurred with an area increase of about $0.02 \mathrm{~km}^{2}$ to $0.11 \pm 0.002 \mathrm{~km}^{2}$ (estimated water volume of $1,459,250 \pm 30,200 \mathrm{~m}^{3}$ ) from July 2014 to 6 August 2014, the day of the flood. After the GLOF event, the lake area decreased to almost its former size of about $0.09 \pm 0.009 \mathrm{~km}^{2}$. The estimated released water volume, derived from the difference of the lake volume using satellite data from shortly before and after the event, using the empirical lake volume formula (Huggel et al. 2002) amounts to $360,650 \pm 123,600 \mathrm{~m}^{3}$. The peak discharge $\left(\mathrm{Q}_{\max }\right)$ amounts to $23 \pm 6 \mathrm{~m}^{3} \mathrm{~s}^{-1}$. However, considering the lake area and lowering of lake level by about $5 \mathrm{~m}$ (derived from TanDEM-X (Fig. 8) and verified by field observation (Fig. 6), the estimated discharge ranges from 450,000 to $600,000 \mathrm{~m}^{3}$ with an estimated peak discharge between 27 and $32 \mathrm{~m}^{3} \mathrm{~s}^{-1}$. A lake level fluctuation of a similar magnitude can also be detected in September 1998, when the lake size was reduced to $81 \%$ of its previous extent, releasing an estimated water volume of $237,600 \pm 53,500 \mathrm{~m}^{3}$. Due to the insufficient temporal resolution of satellite images from that period, a GLOF event cannot be stated with confidence; however, according to some elderly villagers, a flood without rain in the catchment, inundating some fields, occurred three decades ago (own interviews, September 2014). Recent rapid lake level rise can be detected in August 2019, when the lake reached the same level as in 2014 before it decreased to its former level between August and September (Fig. 8). The estimated released water volume was 155,900 $\pm 9200 \mathrm{~m}^{3}$ (according to the empirical formula by Huggel et al. 2002) and 204,000 to $219,000 \mathrm{~m}^{3}$ according to lake level differences; however, a flood was not observed in the village (personal communication Stangzin Dorjei Gya, 20.02.2020) and was not evident during the field survey in late 

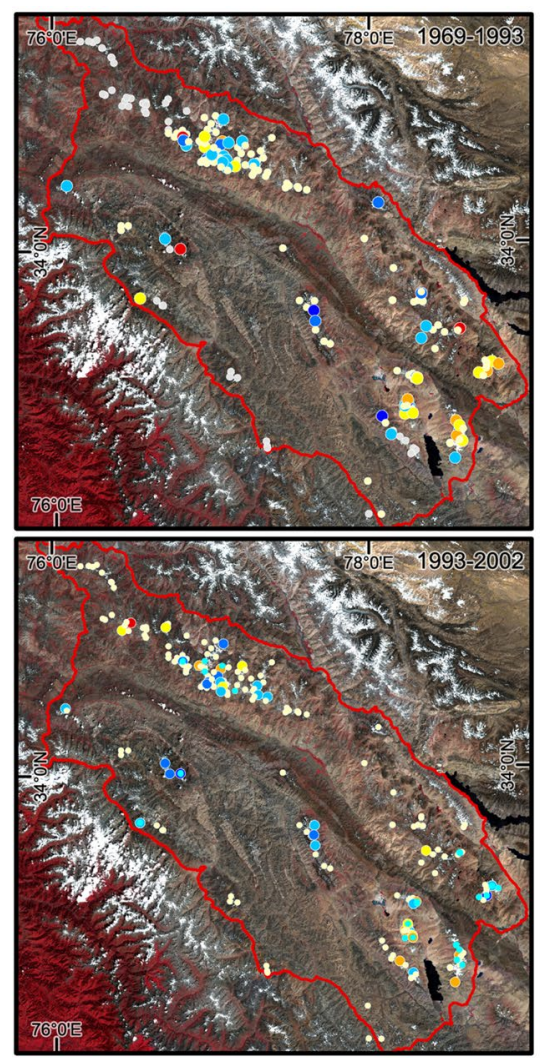

Volume change in $\mathrm{m}^{3}$

NoData

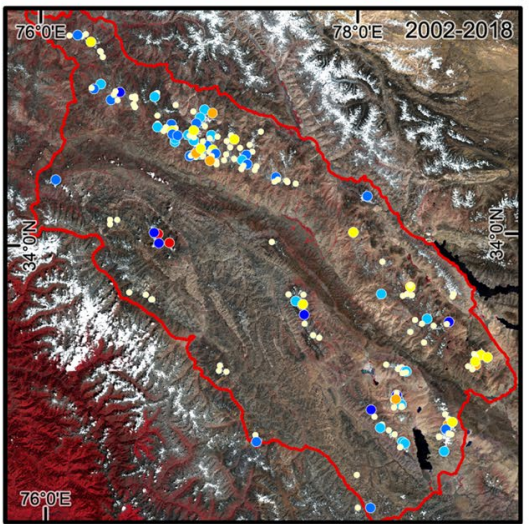

- <-500,000

$-500000--200,001$

$-200,000--100,001$

$-100,000-100,000$

- $100,001-200,000$

- $200,001-500,000$

- $>500,000$

$\square$ Study area

$\begin{array}{lllll}0 & 25 & 50 & 75 & 100\end{array}$

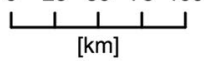

Background: Sentinel 2 mosaic

2018-08-28: T44SLB-SLD, T44SKB-SKD

T43SGS-SGU, T43SFS-SFU

2018/08/06: T43SEU, SFU

2018/08/13: T43SFT

2018/09/20: T43SES-SET, SFS

(scihub.copernicus.eu)

Draft \& cartography: S. Schmidt, N. Harm

Fig. 5 Estimated lake volume changes in 1969-1993, 1993-2002 and 2002-2014 in the Trans-Himalayan region of Ladakh

August 2019. Thus, a slow water release must be assumed, also supported by the image from 11 September, when the lake level already began to sink. 


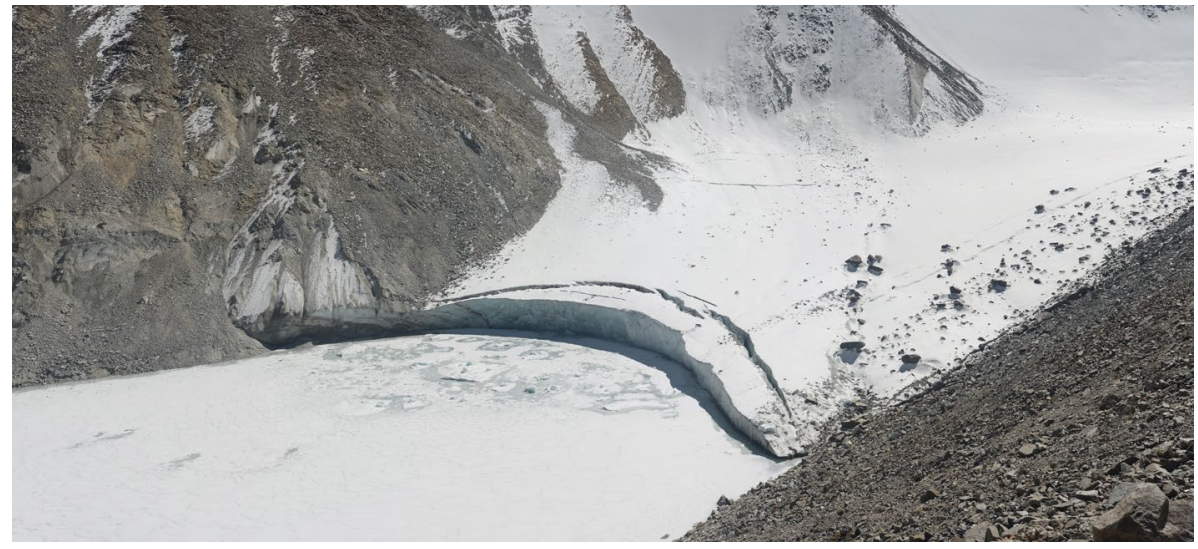

Fig. 6 The ice-covered Gya lake at $5400 \mathrm{~m}$ a.s.l. The topographical setting of the site is characterized by instable slopes with buried ice. Crevasses near the glacier front show the potential of calving, posing an additional risk for future GLOF events (Photograph: Marcus Nüsser, 2 October 2014)

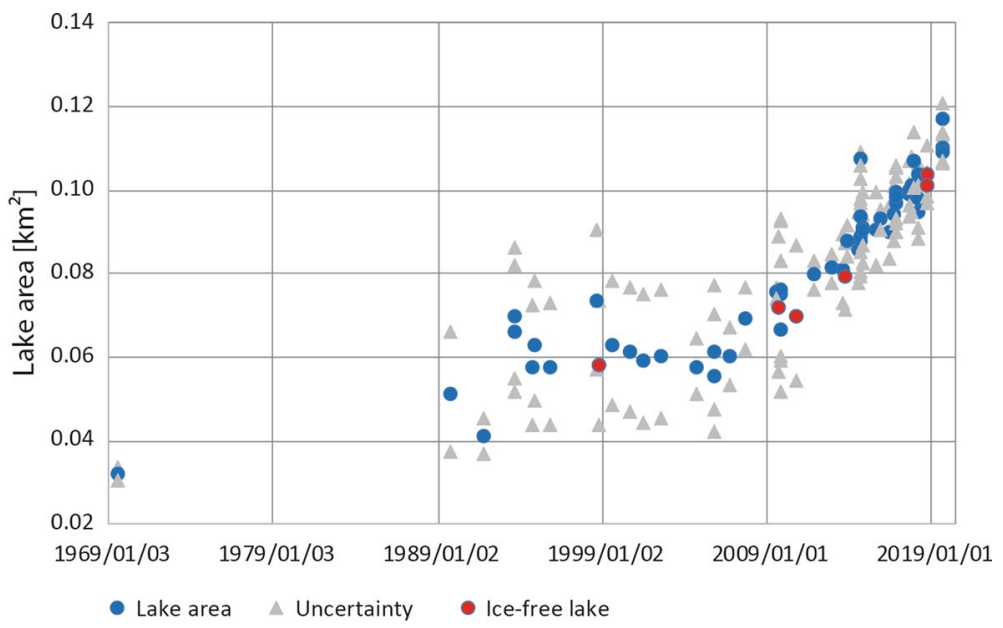

Fig. 7 Glacial Lake development between 1969 and 2019. For the period up to 2014, primarily 29 Landsat images were used, from 2014 on these were supplemented by 12 Sentinel and 7 PlanetScope data with higher spatial resolution (plus 9 images from various sensors); only on 6 satellite images, the lake surface was completely ice free, and on 14 images, some ice blocks could be detected on the lake. On all other images, the lake is totally or partly covered by ice

\subsubsection{Flood event in $\mathbf{2 0 1 4}$}

Field observations in September 2014 show that the moraine between the proglacial lake and the thermokarst hollow was not eroded and no fluvial sediments were accumulated. Fine-grained sediments with some small ripple marks were only found to a limited extent near the thermokarst hollow (Fig. 8). One individual plant (Thylacospermum caespitosum) was found in the channel, whereas sandy sediments were absent (Fig. 9). Furthermore, the satellite image taken at 11 a.m. on the day of the GLOF event displays a high water 


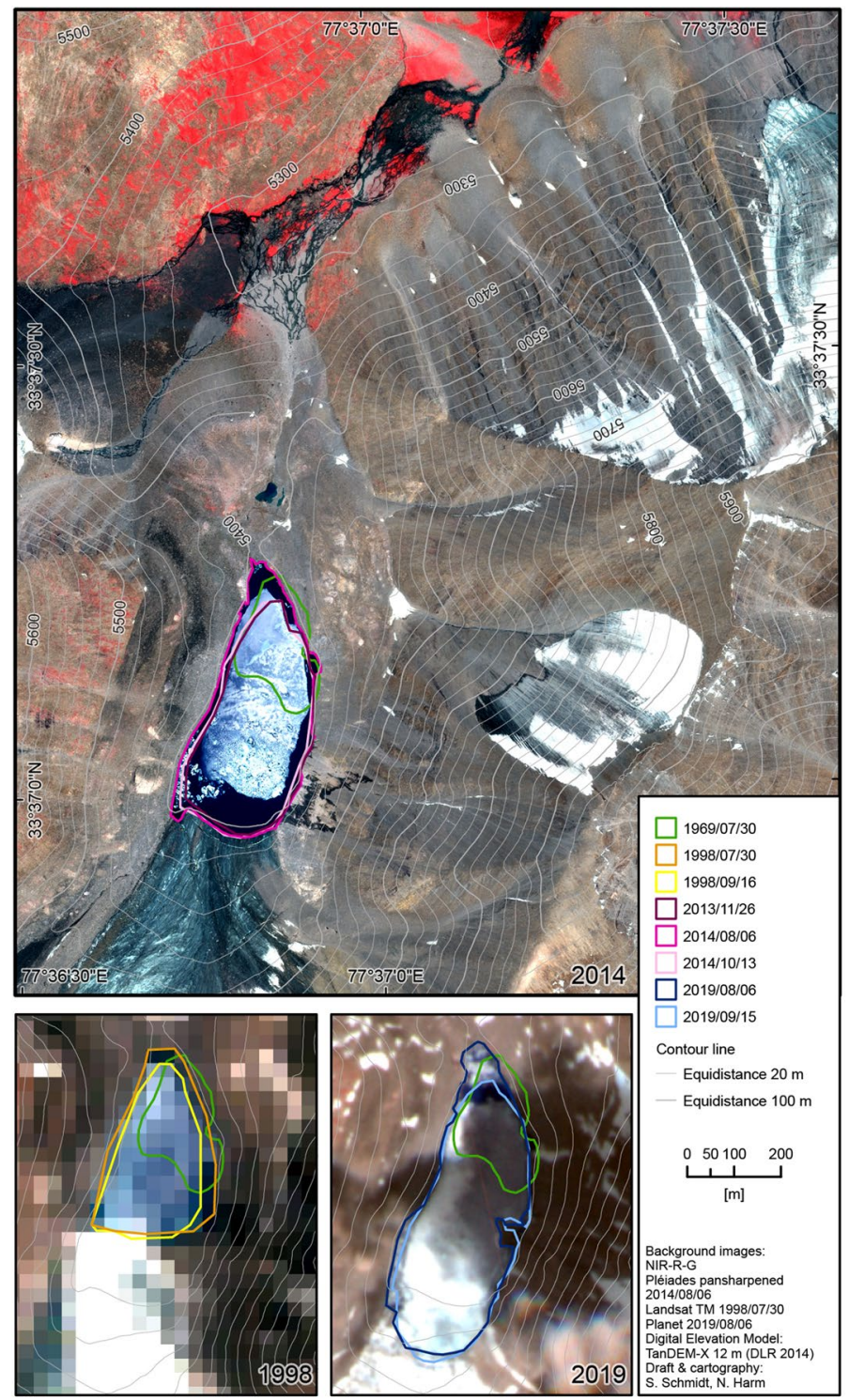

Fig. 8 Proglacial lake of Gya-the lake levels before and after the GLOF as well as the lake level changes in 1998 and 2019 are shown. The contour lines derived from TanDEM-X indicate the depression and desiccated channel cutting the moraine. In front of the moraine, the large amount of melt water is detectable

discharge at around $5300 \mathrm{~m}$ a.s.1. (Fig. 8). These observations suggest that not a spillover but rather a subsurface (tunneling) drainage process occurred, which resulted from thawing of ice cores in the moraine. The observed rapid increase in the lake level can be attributed to increased snow and glacier melting or temporary blockage of the tunneling system. After the outburst, the lake reverted to its previous level as mapped for 2013 using RapidEye data. The Pléiades image from 6 August 2014 and the TanDEM-X indicate a reduction in 


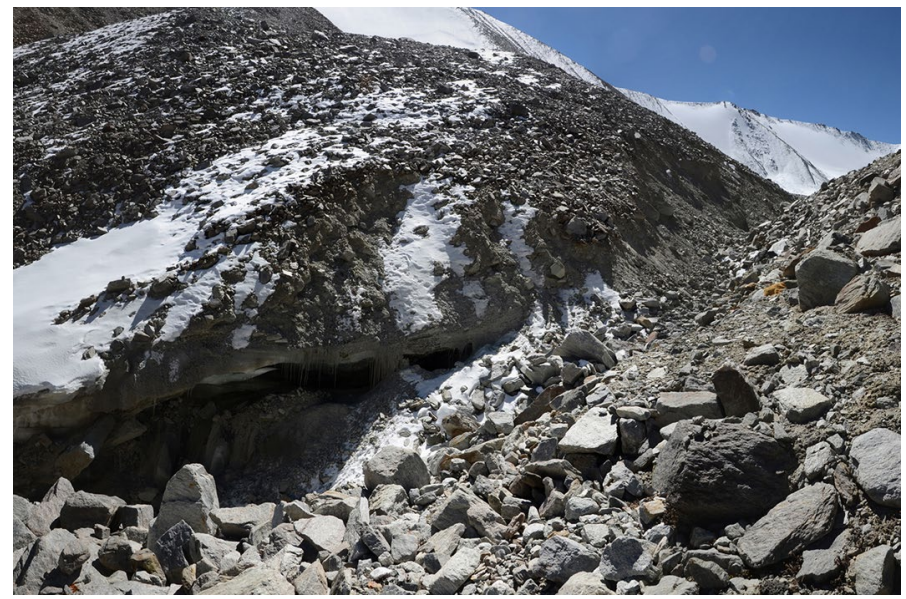

Fig. 9 Desiccated channel cutting the terminal moraine at around $5370 \mathrm{~m}$ a.s.1. (Photograph: Marcus Nüsser, 2 October 2014)

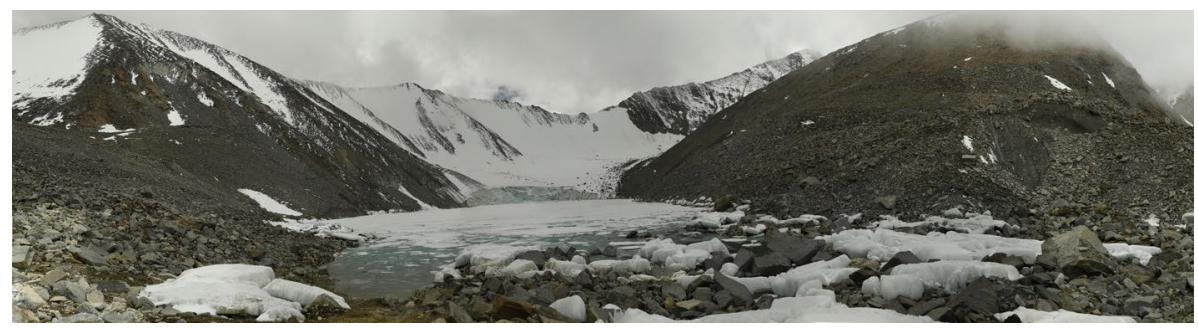

Fig. 10 The ice-covered Gya lake at $5400 \mathrm{~m}$ a.s.1. Deposited fragments of surface ice along the northern lake shore indicating a previously higher lake level (Photograph: Marcus Nüsser, 28 August 2019)

vertical distance between the depression and the lake surface of about $2 \mathrm{~m}$. Remote sensing imagery and the field survey in August 2019 showed a similar situation regarding lake level and extent (Fig. 10).

Downstream of the terminal moraine, drainage occurs in several river channels, but a sediment tail could be detected neither on remote sensing data nor during the field survey. The run-off was dammed by various blocky talus cones located between 0.4 and $2.2 \mathrm{~km}$ downstream of the terminal moraine, resulting in temporary waterlogging in the upper catchment (Figs. 8, 11). These waterlogged sections were identified in the field by fine-grained sediments and in some places by intact Kobresia turf. As water run-off was not detectable in some talus cones, subsurface flow through the cones can be assumed. In lower valley sections with slope gradients between $5^{\circ}$ and $7^{\circ}$ and broad valley bottoms, the flood dispersed over a width of up to $90 \mathrm{~m}$, four times more than the average width of the channel. Intense fluvial incision and lateral erosion of unconsolidated material were detectable in the field, and the corresponding large sediments loads were accumulated in lower valley sections. These are also traceable on satellite images (Fig. 12). Due to the cumulative effect of temporary blockage in the upper valley section and lateral widening in some portions, the flood slowed down so that shepherds were able to warn villagers of the approaching hazard. Villagers reported the black colour and unusual smell of water, 


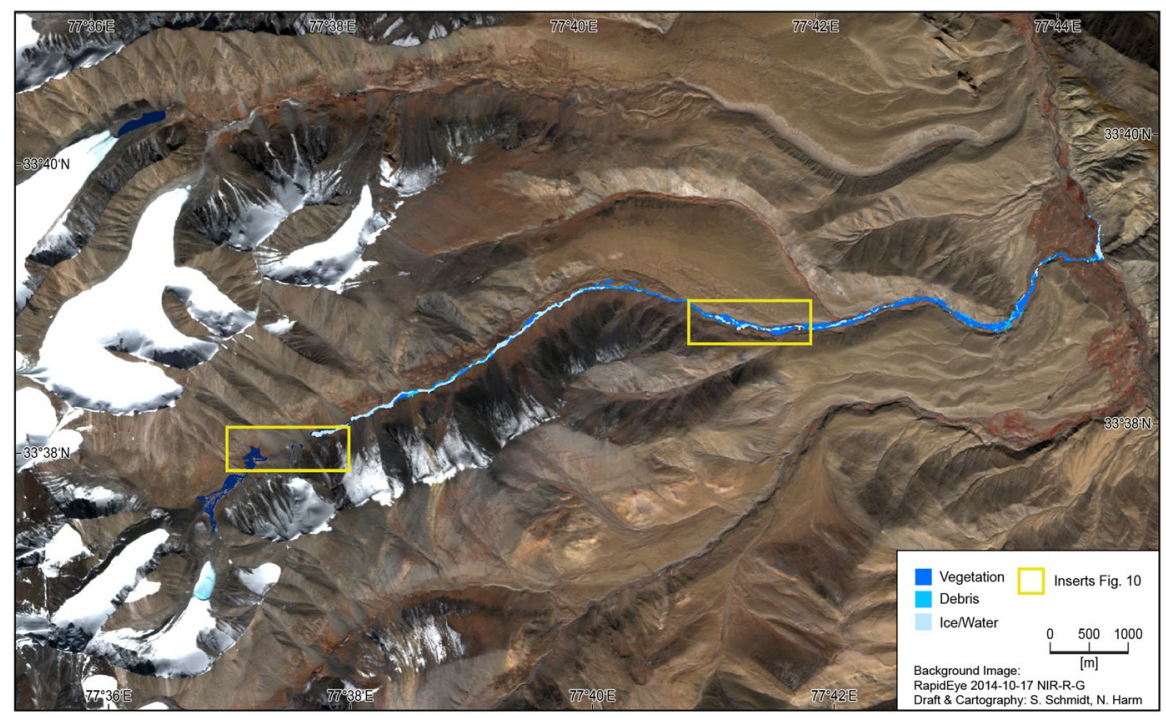

Fig. 11 Gya valley with reconstruction of the GLOF-the conducted change detection analysis shows the flooded area classified into three cover type dynamics: vegetation to debris, modified debris and ice-covered to debris-covered area

indicating a high sediment load rich in organic material originating from wetlands in the upper valley section.

In the lower valley section above the village (Fig. 13), the channel narrows to less than $15 \mathrm{~m}$. This constriction was aggravated by a concrete bridge with massive pillars, built in the 2000s, which was destroyed by the flood. A small footbridge and irrigation canal intakes were also completely damaged. Two sharp and narrow curves increased lateral erosion of the more than 5-m-thick fluvial terrace and inundation of further downstream, where $4000 \mathrm{~m}^{2}$ of cultivated area, mostly located on the orographic right side, was eroded.

Further downstream, the water dispersed to the wider floodplain, where it destroyed two watermills and two houses and flooded two more houses in front of the Leh-Manali highway, which was only partly damaged. According to field observations, the flood reached a depth of more than $2 \mathrm{~m}$ in the village. After the flood, concrete walls (up to $2 \mathrm{~m}$ in height) were constructed along the undercut bank as flood protection measures. Some of them were partially damaged and dysfunctional in August 2019. Downstream, new gabions on both sides of the channel, two footbridges and one motorable concrete bridge were built, narrowing the floodplain to a dangerous extent. Interviews showed that villagers are aware of future GLOF risk and potential economic loss due to destroyed fields and damaged infrastructure.

\section{Discussion}

Due to the lack of standards for glacial lake mapping, the minimum size of assessed glacial lakes varies widely $\left(0.0005 \mathrm{~km}^{2}\right.$ in Bhambri et al. 2018; $0.001 \mathrm{~km}^{2}$ in Narama et al. 2018; $0.003 \mathrm{~km}^{2}$ in Shrestha et al. 2017; $0.0036 \mathrm{~km}^{2}$ in Gardelle et al. 2011;0.01 km² in Wang et al. 2015 and Worni et al. 2013; $0.02 \mathrm{~km}^{2}$ in Wang et al. 2015). This lack of 

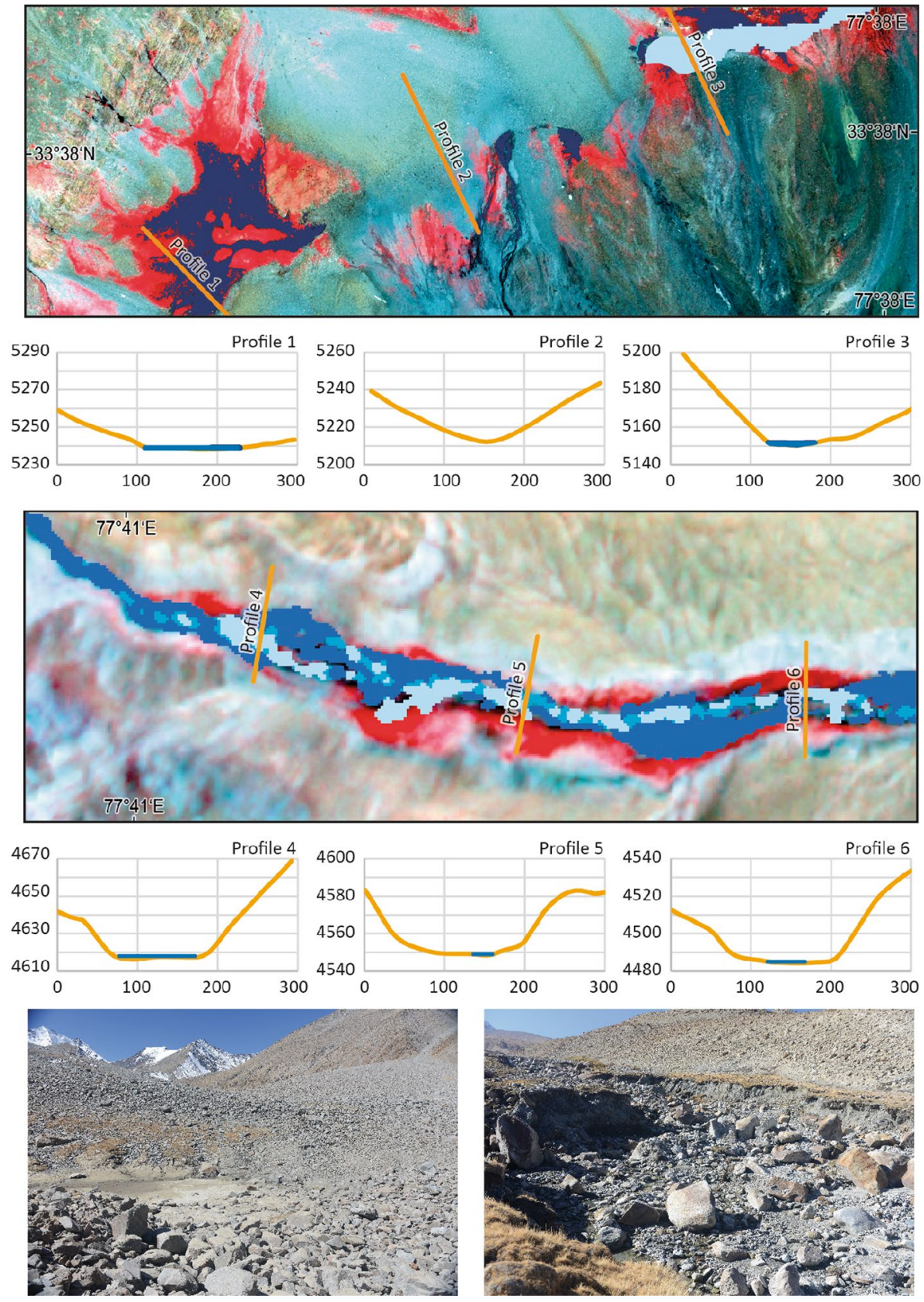

Fig. 12 Detailed valley cross sections along the Gya valley - the blue lines indicate flooded areas. The photographs show the situation in profile 2 (left) and profile 5 (right) (Photographs: Marcus Nüsser, 3 October 2014)

consistency makes comparison difficult, yet it is necessary to choose an appropriate minimum size based on local conditions and the purpose of research. In this study, only glacial 

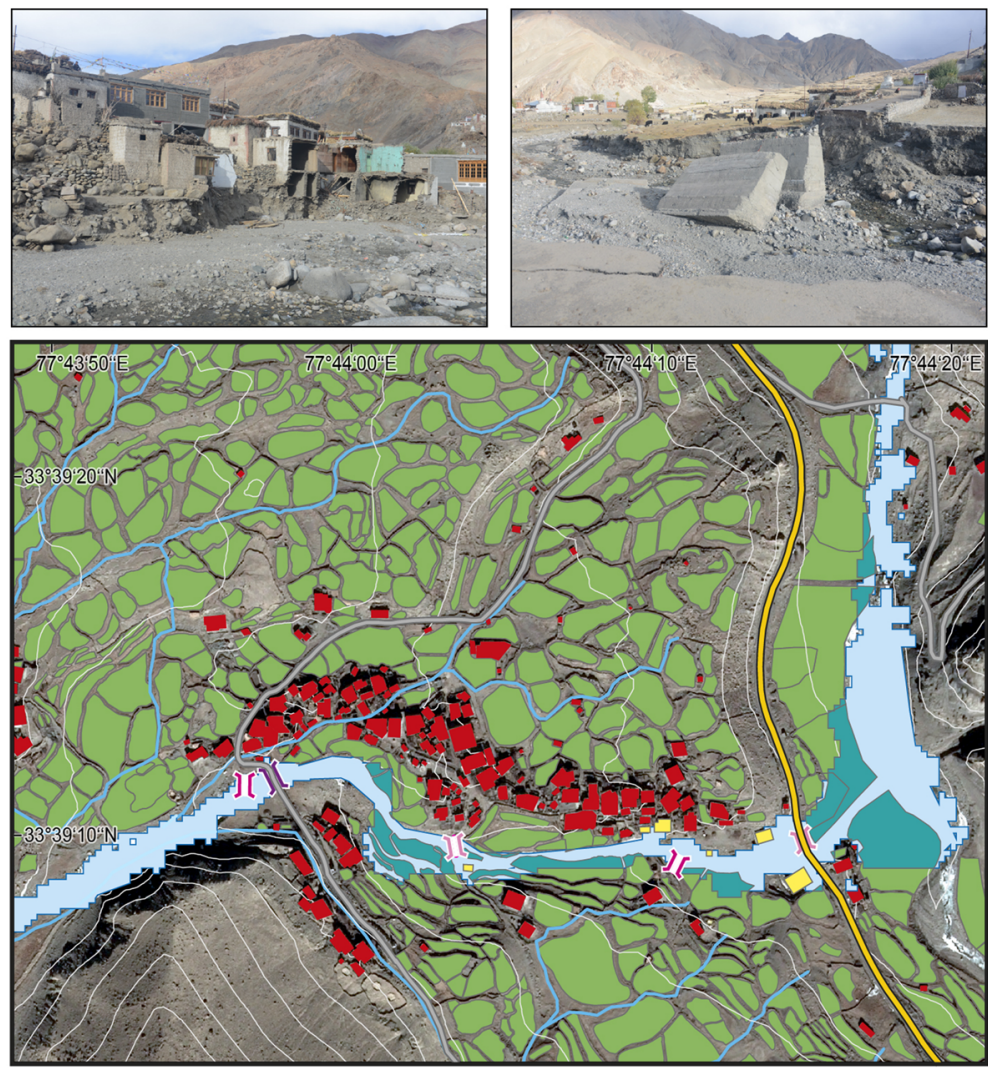

$\square$ Damaged building
$\square$ Flooded/eroded field
$\square$ Flooded Area
$\square$ Building
$\square$ Irrigated field
- Canal

$$
\begin{aligned}
=\text { Road } \\
=\text { Highway } \mathrm{NH} 3 \\
=\text { Destroyed motorable bridge (concrete) } \\
=\text { Destroyed footbridge (stone/wood) } \\
=\text { Partly damaged bridge } \\
\quad \text { Contour line (equidistance } 10 \mathrm{~m} \text { ) }
\end{aligned}
$$

Background Image: SPOT 6 R-G-B 2013/11/18 Data Source: SPOT 6 R-G-B 2013/11/18, HMA-DEM $8 \mathrm{~m}$ Draft \& Cartography: S. Schmidt, M. Nüsser, N. Harm

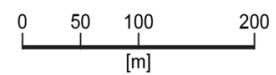

Fig. 13 The flooded area in Gya village and damages due to the 2014 GLOF (Photographs: Marcus Nüsser, 30 September 2014)

lakes larger than $9000 \mathrm{~m}^{2}$ (with an estimated water volume of about 43,000 $\mathrm{m}^{3}$ ) were considered. As many glacial lakes in Ladakh are ice-covered even in summer-evident in the time-series of the Gya lake - their detection by semi-automatic approaches is not possible; and time-consuming controls by visual interpretation are necessary. The integration of all lakes was not practicable considering the size of the mapped area and the spatial resolution of Landsat 5 imagery. Thus, the total number of glacial lakes in Ladakh is much higher than the 192 identified and used for this inventory.

The change detection analyses show that the number and size of glacial lakes have increased since 1969, which is similar to the observed trend in the entire Himalayan region (Bolch et al. 2019). The relative increase in the total glacial lake area, which amounts to 
35\% in the Trans-Himalayan region of Ladakh between 1993 and 2018, is lower than the observed trend for the eastern Himalaya and Spiti Lahaul (Gardelle et al. 2011; Nie et al. 2017; Sharma et al. 2018). Corresponding to the small size of the glaciers in the TransHimalayan region of Ladakh (Schmidt \& Nüsser 2017), the glacial lakes are comparably small and only $6 \%$ are larger than $100,000 \mathrm{~m}^{2}$. Lake changes in Ladakh show a heterogeneous pattern varying from increasing to decreasing lake sizes and recurrent fluctuations. This is similar to observations made by Ashraf et al. (2017) for the adjacent Karakoram, by Shrestha et al. (2017) for the Koshi basin and by Nie et al. (2018) along the Himalayan arc.

The case of Gya underlines the potential hazard of these overlooked lakes. For instance, either due to the ice cover or due to its size being under the threshold of $0.01 \mathrm{~km}^{2}$ and thereby assumed to not present relevant hazard potentials to downstream villages, the Gya lake was not classified as potentially hazardous by Worni et al. (2013). The omission of potentially hazardous lakes can be problematic, as exemplified with the Chorabari lake outburst event in 2013 (Bhambri et al. 2016). Various studies show that small glacial lakes might cause serious damages and can adversely affect local livelihoods, as witnessed in the case of the Domkhar flood in Ladakh (Narama et al. 2012; Ikeda et al. 2016) and several small floods in Hunza (Ashraf et al. 2012; Parveen et al. 2015). The examples show that even minor events may require further investigation as "emerging threats" (Hewitt and Liu 2010). This holds true for large areas of the Trans-Himalaya, where small proglacial lakes are located in many tributaries. Thus, the threshold for identifying potentially hazardous lakes needs to be adjusted according to local expansion of human habitat, infrastructure and agricultural areas (Wang et al. 2012). There is an urgent need to generate glacial lake inventories that include small lakes by using high spatial resolution satellite imagery (Bhambri et al. 2016). Moreover, the hydrological connectivity of several lakes may trigger the outburst of other lakes due to cascading effects (Erokhin et al. 2018; Kirschbaum et al. 2019; Petrakov et al. 2020). A sophisticated monitoring concept should also integrate satellite data with high temporal resolution to indicate the development of short-lived lakes on glaciers or on debris landforms with buried ice (Narama et al. 2012, 2018) or fast glacial lake growth (Petrakov et al. 2020) as also evident in the case of Gya.

Beside an improved lake inventory, more bathymetrical surveys are required for a more precise estimation of lake volumes, as even lakes within similar geographical areas do not necessarily have equally predictable volumes (Cook and Quincey 2015). Nevertheless, various empirical formulae have been developed based on the relation between volume and area size using small numbers of measured lakes (Sakai et al. 2012 used 17 measurements; Veh et al. 2020 used 24 measurements; Wang et al. 2012 used 20 measurements; Yao et al. 2012 used 15 measurements). Due to limited bathymetrical surveys and differing lake types, the formulae differ significantly and volumes are over- or underestimated, with uncertainties of around $\pm 50 \%$ (Muñoz et al. 2020), ranging up to 400\% (Cook and Quincey 2015). The comparison of Himalayan lake volumes listed in Veh et al. (2020; excluding the Chorabari lake) and calculated volumes based on the empirical formula by Huggel et al. (2002) indicates that in 8 cases the error is less than $\pm 25 \%$, in 11 cases it ranges between $\pm 25-50 \%$, and in 4 cases it is even larger than $\pm 50 \%$. The estimated water discharge derived from lake level differences and empirical formulae differ by about 25 to $66 \%$ for the case of Gya. This suggests that the uncertainty in lake volume is primarily due to the absence of bathymetry data rather than errors in measuring lake area and formulae may need to be adapted to local conditions based on bathymetric surveys.

The change detection analyses show that in total 18 lakes released water of more than $200,000 \mathrm{~m}^{3}$ between 1969 and 2018 . It cannot be stated with confidence that each of these water releases caused a GLOF, as some lakes might have drained over longer periods as 
shown for the Gya lake in August 2019. However, at least two cases match with GLOF events in Ladakh reported by Morup (2014). Many GLOFs might be unobserved or unreported due to the sparsely populated area, as in other Himalayan regions (Nie et al. 2018; Veh et al. 2018). On the other hand, some reported GLOFs (Morup 2014; Tabassum and Kanth 2013) could not be verified as no glacial lakes could be identified on satellite imagery within the relevant period. Therefore, in some cases it might be assumed that the reported floods have been caused by cloudbursts. This reflects the general problem of unknown hazards and understated risk that can result from inventories that rely on only a single method of classification or satellite imagery of lower spatial resolution.

As demonstrated in the case of the Gya GLOF, a false sense of security can result in maladaptive behaviour. This means that in spite of the additional effort required, establishing the robustness of such inventories through multiple independent methods may be necessary. Multi-criteria guidelines (Worni et al. 2013) may help to systematically categorize the individual lake hazard. However, the assessment of different variables by using remote sensing data can be difficult, as the freeboard height between lake level and moraine crest needs a DEM with a high spatial resolution; or even on satellite images with high spatial resolution the identification of buried ice in moraines as well as water discharge by tunneling processes cannot be detected. More field observations and measurements are therefore required. Tunneling processes can be assumed as a trigger of sudden water releases in various events (Erokhin et al. 2018; Ikeda et al. 2016; Narama et al. 2018). Furthermore, glacial lakes with an underground drainage are more susceptible to outburst floods than lakes with a stable surface drainage, because intra-moraine channels can be blocked by thermokarst processes (Narama et al. 2018), so that the blockage can lead to overflow and subsequent lake outburst through erosion and breach formation (Erokhin et al. 2018; Petrakov et al. 2012, 2020). The ice tunnel can be closed and the lake can be refilled again; thus, several floods can occur from the same glacial lake (Narama et al. 2018) or indicated by the lake level changes in Gya. The time series of Gya indicates a rapid increase in the lake level before the GLOF event in 2014 as well as in 2019. Whether these lake level rises are caused by a blockage of the tunnel or by an increase in melt water due to a massive heatwave as reported by the villagers of Gya in 2014 or high precipitation as observed in 2019 remains unclear. Both abrupt rise of temperature and torrential rainfall may act as triggering factors for GLOFs (Din et al. 2014; Erokhin et al. 2018; Petrakov et al. 2020). The widening of the tunnel system within the moraines and melting of buried ice may increase the future risk of GLOFs (Richardson and Reynolds 2000; Sakai 2012; Westoby et al. 2014; Worni et al. 2013).

As tunneling processes do not necessarily destroy the shape of moraines and drainage lines cross blocky material of scree and talus cones allowing sub-surface flow, the identification of former GLOF events based primarily on sediment tails (Veh et al. 2018, 2019) or V-shaped trench (Komori et al. 2012; Nie et al. 2018) may be misleading. This means that the investigation of GLOF events caused by tunneling is important for further hazard assessments because it raises the question whether moraine dam failure, including overtopping, is the most common or just the most detectable form of GLOF. Due to the large number of unreported GLOF events and uncertainty about outburst mechanisms, this question deserves particular attention.

Besides the growing risk of GLOFs due to climate change, the vulnerability of local communities increases. Due to population growth and migration processes, habitations expand in most tributaries with dispersed settlement structures including new roads and bridges. As in other regions of the Himalaya (Hewitt and Mehta 2012), this results in potentially high exposure to cryosphere hazards along the river channels, even in areas 
without documented GLOFs. The integration of cryosphere change with its broader social context, as considered within the emerging field of socio-hydrology in climate-sensitive mountain regions (Nüsser 2017; Nüsser et al. 2019), offers a useful framework for such an analysis of the dynamic coupling of cryosphere hazards and societal response (Mukherji et al. 2019).

\section{Conclusion}

In the light of recurring GLOFs in Ladakh, the exposure of local populations to cryosphere hazards needs to be re-evaluated, with consequences for identification of vulnerability and the necessity for adaptation measures. This article offers a method for identifying exposure and the occurrence of GLOFs using analyses of satellite imagery. This is especially useful in cases where oral history is unreliable or where outbreak events occur far from habitation and such floods are simply classified as flash floods of uncertain origins. The reliability of this method could further be established using field research and ground truthing. The consilience and robustness of the methods described here can be thus established using two unrelated forms of detection.

Acknowledgements Open Access funding provided by Projekt DEAL. Research was funded by the South Asia Institute (SAI), Heidelberg University, and the Heidelberg Centre for the Environment (HCE), Heidelberg University. We gratefully acknowledge their support. The German Aerospace Center (DLR) kindly provided TanDEM-X data, the European Space Agency (ESA), Blackbridge (RESA-Project) and PlanetScope for providing satellite imagery. Earlier versions of this research have been presented at the EGU General Assembly 2016 and other international conferences. Two reviewers provided feedback that helped us to substantially improve this article.

Funding Research was funded by the South Asia Institute (SAI), Heidelberg University, and the Heidelberg Centre for the Environment (HCE), Heidelberg University.

Code availability Software application or custom code not applicable.

\section{Compliance with ethical standards}

Conflict of interest Not applicable.

Availability of data and material Data transparency.

Open Access This article is licensed under a Creative Commons Attribution 4.0 International License, which permits use, sharing, adaptation, distribution and reproduction in any medium or format, as long as you give appropriate credit to the original author(s) and the source, provide a link to the Creative Commons licence, and indicate if changes were made. The images or other third party material in this article are included in the article's Creative Commons licence, unless indicated otherwise in a credit line to the material. If material is not included in the article's Creative Commons licence and your intended use is not permitted by statutory regulation or exceeds the permitted use, you will need to obtain permission directly from the copyright holder. To view a copy of this licence, visit http://creativecommons.org/licenses/by/4.0/.

\section{References}

Ali NS, Quamar FM, Phartiyal B, Sharma A (2018) Need for permafrost researches in Indian Himalaya. J Clim Change 4:33-36. https://doi.org/10.3233/JCC-180004 
Allen SK, Linsbauer A, Randhawa SS, Huggel C, Rana P, Kumari A (2016a) Glacial lake outburst flood risk in Himachal Pradesh, India: an integrative and anticipatory approach considering current and future threats. Nat Hazards 84:1741-1763. https://doi.org/10.1007/s11069-016-2511-x

Allen SK, Rastner P, Arora M, Huggel C, Stoffel M (2016b) Lake outburst and debris flow disaster at Kedarnath, June 2013: hydrometeorological triggering and topographic predisposition. Landslides 13:1479-1491. https://doi.org/10.1007/s10346-015-0584-3

Ashraf A, Naz R, Iqbal MB (2017) Altitudinal dynamics of glacial lakes under changing climate in the Hindu Kush, Karakoram, and Himalaya ranges. Geomorphology 283:72-79. https://doi.org/10.1016/j. geomorph.2017.01.033

Bajracharya SR, Mool PK (2009) Glaciers, glacial lakes and glacial lake outburst floods in the Mount Everest region. Nepal Ann Glaciol 50:81-86

Bhambri R, Hewitt K, Kawishwar P, Kumar A, Verma A, Snehmani TS, Misra A (2019) Ice-dams, outburst floods, and movement heterogeneity of glaciers, Karakoram. Glob Planet Change 180:100-116. https:// doi.org/10.1016/j.gloplacha.2019.05.004

Bhambri R, Mehta M, Dobhal DP, Gupta AK, Pratap B, Kesarwani K, Verma A (2016) Devastation in the Kedarnath (Mandakini) Valley, Garhwal Himalaya during 16th-17th June, 2013: A remote sensing and ground based assessment. Nat Hazards 80:1801-1822. https://doi.org/10.1007/s11069-015-2033-y

Bhambri R, Mishra A, Kumar A, Gupta AK, Verma A, Tiwari SK (2018) Glacier lake inventory of Himachal Pradesh. Himalayan Geol 39(1):1-32

Bhambri R, Watson CS, Hewitt K, Haritashya U, Kargel JS, Shahi AP, Sharma P, Kumar A, Verma A, Govil H (2020) The hazardous 2017-2019 surge and river damming by Shispare Glacier. Karakoram Sci Rep 10:4685. https://doi.org/10.1038/s41598-020-61277-8

Bolch T, Peters J, Yegorov A, Pradhan B, Buchroithner M, Blagoveshchensky V (2012) Identification of potentially dangerous glacial lakes in the northern Tian Shan. In: Pradhan B, Buchroithner M (eds) Terrigenous mass movements. Springer, Heidelberg, pp 369-398. https://doi.org/10.1007/978-3-64225495-6_12

Bolch T, Shea JM, Liu, S (2019) Status and change of the cryosphere in the extended Hindu Kush Himalaya Region. In: Wester P, Mishra A, Mukherji A, Shrestha AB (eds) The Hindu Kush Himalaya Assessment: Mountains, Climate Change, Sustainability and People. Springer International Publishing, Cham, pp 209-255. https://doi.org/10.1007/978-3-319-92288-1_7

Carey M, Molden O, Rasmussen M, Jackson M, Nolin AW, Mark BG (2017) Impacts of glacier recession and declining meltwater on mountain societies. Ann Am Assoc Geogr 107:350-359. https://doi. org/10.1080/24694452.2016.1243039

Carrivick JL, Tweed FS (2016) A global assessment of the societal impacts of glacier outburst floods. Glob Planet Change 144:1-16. https://doi.org/10.1016/j.gloplacha.2016.07.001

Census of India (2011) Census of India 2011. Retrieved January 20, 2020 from - http:// www.census2011 .co.in/census/district/621-leh.html.

Cook SJ, Quincey DJ (2015) Estimating the volume of alpine glacial lakes. Earth Surface Dyn 3:559-575. https://doi.org/10.5194/esurf-3-559-2015

Cunningham SA (1854) Ladák: physical, statistical, and historical; with notices of the surrounding countries. London.

Din K, Tariq S, Mahmood A, Rasul G (2014) Temperature and precipitation: GLOF triggering indicators in Gilgit-Baltistan. Pak Pak J Meteorol 10(20):39-56

Dolma R (2014) Floods in Gya: Lessons for Ladakh. Stawa 1(4):4-6

Emmer A (2018) GLOFs in the WOS: bibliometrics, geographies and global trends of research on glacial lake outburst floods (Web of Science, 1979-2016). Nat Hazards Earth Syst Sci 18:813-827. https:// doi.org/10.5194/nhess-18-813-2018

Emmer A, Vilímek V (2013) Lake and breach hazard assessment for moraine-dammed lakes: an example from the Cordillera Blanca (Peru). Nat Hazards Earth Syst Sci 13:1551-1565. https://doi.org/10.5194/ nhess-13-1551-2013

Erokhin SA, Zaginaev VV, Meleshko AA, Ruiz-Villanueva V, Petrakov DA, Chernomorets SS, Viskhadzhieva KS, Tutubalina OV, Stoffel M (2018) Debris flows triggered from non-stationary glacier lake outbursts: the case of the Teztor Lake complex (Northern Tian Shan, Kyrgyzstan). Landslides 15(1):83-98. https://doi.org/10.1007/s10346-017-0862-3

Gardelle J, Amaud Y, Berthier E (2011) Contrasted evolution of glacial lakes along the Hindu Kush Himalaya mountain range between 1990 and 2009. Glob Planet Change 75:47-55. https://doi.org/10.1016/j. gloplacha.2010.10.003

Gazetteer of Kashmir and Ladák (1890) together with routes in the territories of the Maharája of Jamú and Kashmir, compiled under the direction of the Quarter Master General in India in the Intelligence Branch, Calcutta, India 
Government of Jammu \& Kashmir (2011-2012) Blockwise Village Amenity Directory:67

Haritashya UK, Kargel JS, Shugar DH, Leonard GJ, Strattman K, Watson CS, Shean D, Harrison S, Mandli KT, Regmi D (2018) Evolution and controls of large glacial lakes in the Nepal Himalaya. Remote Sens 10:798. https://doi.org/10.3390/rs10050798

Harrison S, Kargel JS, Huggel C, Reynolds J, Shugar DH, Betts RA, Emmer A, Glaser N, Haritashya UK, Klimeš J, Reinhardt L, Schaub Y, Wiltshire A, Regmi D, Vilímek V (2018) Climate change and the global pattern of moraine-dammed glacial lake outburst floods. The Cryosphere 12(4):1195-1209. https://doi.org/10.5194/tc-12-1195-2018

Hewitt K (1982) Natural dams and outburst floods of the Karakoram Himalaya. In: Hydrological aspects of alpine high mountain areas. IAHS 138:259-269.

Hewitt K, Liu JS (2010) Ice-dammed lakes and outburst floods, Karakoram Himalaya: Historical perspectives on emerging threats. Phys Geogr 31:528-551. https://doi.org/10.2747/0272-3646.31.6.528

Hewitt K, Mehta M (2012) Rethinking risk and disasters in mountain areas. Revue de géographie alpine. https://doi.org/10.4000/rga.1653

Hock R, Rasul G, Adler C, Cáceres B, Gruber S, Hirabayashi Y, Jackson M, Kääb A, Kang S, Kutuzov S, Milner Al, Molau U, Morin S, Orlove B, Steltzer H (2019) High Mountain Areas. In: Pörtner B, Roberts DC, Masson-Delmotte V, Zhai P, Tignor M, Poloczanska E, Mintenbeck K, Alegría A, Nicolai M, Okem A, Petzold J, Rama B, Weyer NM (eds.) IPCC special report on the ocean and cryosphere in a changing climate: 131-202. Retrieved January 20, 2020 from - https://www.ipcc.ch/srocc/chapter/ chapter-2/ last call 2020/03/03

Huggel C, Kääb A, Haeberli W, Teysseire P, Paul F (2002) Remote sensing based assessment of hazards from glacier lake outburst: a case study in the Swiss Alps. Can Geotech J 39:316-330. https://doi. org/10.1139/T01-099

Huss M, Hock R (2018) Global-scale hydrological response to future glacier mass loss. Nat Clim Change 8:135-140. https://doi.org/10.1038/s41558-017-0049-x

Hussain Dahri Z, Ludwig F, Moors E, Ahmad B, Khan A, Kabat P (2016) An appraisal of precipitation distribution in the high-altitude catchments of the Indus basin. Sci Total Environ 548-549:289-306. https ://doi.org/10.1016/j.scitotenc.2016.01.001

Ikeda N, Narama C, Gyalson S (2016) Knowledge sharing for disaster risk reduction: Insights from a glacier lake workshop in the Ladakh Region, Indian Himalayas. Mountain Res Dev 36:31-40. https://doi. org/10.1659/MRD-JOURNAL-D-15-00035.1

Immerzeel WW, van Beek LPH, Bierkens MFP (2010) Climate change will affect the Asian water towers. Sci 328:1382-1385. https://doi.org/10.1126/science.1183188

Iturrizaga L (2019) Historical beacon fire lines as early warning systems for glacier lake outbursts in the Hindu Kush-Karakoram Mountains. Nat Hazards 99:39-70. https://doi.org/10.1007/s11069-019-03705 $-1$

Ives JD, Shrestha RB, Mool PK (2010) Formation of glacial lakes in the Hindu Kush-Himalayas and GLOF risk assessment. Kathmandu.

Kamp U, Byrne M, Bolch T (2011) Glacier fluctuations between 1975 and 2008 in the Greater Himalaya Range of Zanskar, southern Ladakh. J Mount Sci 8:374-389. https://doi.org/10.1007/s1162 9-011-2007-9

Kirschbaum D, Watson CS, Rounce DR, Sugar DH, Kargel JS, Haritashya UK, Amatya P, Shean D, Anderson ER, Jo M (2019) The state of remote sensing capabilities of cascading hazards over high mountain Asia. Front Earth Sci 7:197. https://doi.org/10.3389/fearth.2019.00197

Komori J, Koike T, Yamanokuchi T, Tshering P (2012) Glacial lake outburst events in the Bhutan Himalayas. Glob Environ Res 16:59-70

Morup T (2014) Blurred visions: are we planning for change? Stawa 1(3):8-9

Mukherji A, Sinisalo A, Nüsser M, Garrard R, Eriksson M (2019) Contributions of the cryosphere to mountain communities in the Hindu Kush Himalaya: a review. Reg Environ Change 19:1311-1326. https:// doi.org/10.1007/s10113-019-01484-w

Muñoz R, Huggel C, Frey H, Cochachin A, Haeberli W (2020) Glacial lake depth and volume estimation based on a large bathymetric dataset from the Cordillera Blanca, Peru. Earth Surf Proc Land 45:15101527. https://doi.org/10.1002/esp.4826

Narama C, Tadono T, Ikeda N, Gyalson S (2012) Characteristics of glacier lakes in the Ladakh Range, western Indian Himalayas. Himal Stud Monogr 13:166-179

Narama C, Daiyrov M, Duishonakunov M, Tadono T, Sato H, Kääb A, Ukita J, Abdrakhmatov K (2018) Large drainages from short-lived glacial lakes in the Teskey Range, Tien Shan Mountains, Central Asia. Nat Hazards Earth Syst Sci 18(4):983-995. https://doi.org/10.5194/nhess-18-983-2018 
Nie Y, Sheng Y, Liu L, Liu S, Zhang Y, Song C (2017) A regional-scale assessment of Himalayan glacial lake changes using satellite observations from 1990 to 2015. Remote Sens Environ 189:1-13. https:// doi.org/10.1016/j.rse.2016.11.008

Nie Y, Liu Q, Wang J, Zhang Y, Sheng Y, Liu S (2018) An inventory of historical glacial lake outburst floods in the Himalayas based on remote sensing observations and geomorphological analysis. Geomorphology 308:91-106. https://doi.org/10.1016/j.geomorph.2018.02.002

Nüsser M (2017) Socio-hydrology: A new perspective on mountain waterscapes at the nexus of natural and social processes. Mount Res Dev 37(4):518-520. https://doi.org/10.1659/MRD-JOURNAL-D-1700101.1

Nüsser M, Schmidt S, Dame J (2012) Irrigation and development in the Upper Indus Basin: Characteristics and recent changes of a socio-hydrological system in central Ladakh, India. Mount Res Dev 32:51-61. https://doi.org/10.1659/MRD-JOURNAL-D-11-00091.1

Nüsser M, Dame J, Parveen S, Kraus B, Baghel R, Schmidt S (2019) Cryosphere-fed irrigation networks in the northwestern Himalaya: Precarious livelihoods and adaptation strategies under the impact of climate change. Mount Res Dev 39(2):R1-R11. https://doi.org/10.1659/MRD-JOURNAL-D-18-00072.1

Parveen S, Winiger M, Schmidt S, Nüsser M (2015) Irrigation systems of Upper Hunza (Karakoram) between persistence and changes. Erdkunde 69(1):69-85. https://doi.org/10.3112/erdkunde.2015.01.05

Petrakov DA, Tutubalina OV, Aleinikov AA et al (2012) Monitoring of Bashkara glacier lakes (Central Caucasus, Russia) and modelling of their potential outburst. Nat Hazards 61:1293-1316. https://doi. org/10.1007/s11069-011-9983-5

Petrakov DA, Chernomorets SS, Viskhadzhieva KS, Dokukin MD, Savernyuk EA, Petrov MA, Erokhin SA, Tutubalina OV, Glazyrin GE, Shpuntova AM, Stoffel M (2020) Putting the poorly documented 1998 GLOF disaster in Shakhimardan River valley (Alay Range, Kyrgyzstan/Uzbekistan) into perspective. Sci Total Environ 724:138287. https://doi.org/10.1016/j.scitotenv.2020.138287

Rasul G, Molden D (2019) The global social and economic consequences of mountain cryospheric change. Front Environ Sci 7:91. https://doi.org/10.3389/fenvs.2019.00091

Richardson SD, Reynolds JM (2000) An overview of glacial hazards in the Himalayas. Quatern Int 65(66):31-47. https://doi.org/10.1016/S1040-6182(99)00035-X

Sakai A (2012) Glacial lakes in the Himalayas: a review on formation and expansion processes. Glob Environ Res 16:23-30

Schmidt S, Nüsser M (2012) Changes of high altitude glaciers from 1969 to 2010 in the Trans-Himalayan Kang Yatze Massif, Ladakh, northwest India. Arct Antarct Alp Res 44:107-121. https://doi. org/10.1657/1938-4246-44.1.107

Schmidt S, Nüsser M (2017) Changes of high altitude glaciers in the Trans-Himalaya of Ladakh over the past five decades (1969-2016). Geosciences 7(2):27. https://doi.org/10.3390/geosciences7020027

Sharma RK, Pradhan P, Sharma NP, Shresta DG (2018) Remote sensing and in situ-based assessment of rapidly growing South Lhonak glacial lake in eastern Himalaya, India. Nat Hazards 93:393-409. https ://doi.org/10.1007/s11069-018-3305-0

Shean D (2017) High mountain Asia 8-meter DEM mosaics derived from optical imagery, Version 1. [Indicate subset used]. Boulder, Colorado USA. NASA National Snow and Ice Data Center Distributed Active Archive Center. https://doi.org/10.5067/KXOVQ9L172S2. [2020/01/02].

Sheikh AG (2015) Floods in Ladakh: a glimpse through recent history. Stawa 2(9):8-10

Shrestha F, Xiao G, Khanal NR, Shrestha RB, Li-Zong W, Mool PK, Bajracharya SR (2017) Decadal glacial lake changes in the Koshi basin, central Himalaya, from 1977 to 2010, derived from Landsat satellite images. J Mount Sci 14(10):1969-1984. https://doi.org/10.1007/s11629-016-4230-x

Sinclair MC (1929) The glaciers of the Upper Shyok in 1928. Geogr J 74:383-387

Tabassum N, Kanth TA (2013) An overview of disasters in Leh with special reference to glacial lake outburst floods. Indian J Landsc Syst Ecol Stud 36:50-56

Thayyen RJ, Dimri AP, Kumar P, Agnihotri G (2013) Study of cloudburst and flash floods around Leh, India, during August 4-6, 2010. Nat Hazards 65:2175-2204. https://doi.org/10.1007/s11069-012-0464-2

Veh G, Korup O, Roessner S, Walz A (2018) Detecting Himalayan glacial lake outburst floods from Landsat time series. Remote Sens Environ 207:84-97. https://doi.org/10.1016/j.rse.2017.12.025

Veh G, Korup O, von Specht S, Roessner S, Walz A (2019) Unchanged frequency of moraine-dammed glacial lake outburst floods in the Himalaya. Nat Clim Change 9:379-383. https://doi.org/10.1038/s4155 8-019-0437-5

Veh G, Korup O, Walz A (2020) Hazard from Himalayan glacier lake outburst floods. Proc Natl Acad Sci 117(2):907-912. https://doi.org/10.1073/pnas.1914898117

Vuichard D, Zimmermann M (1987) The 1985 catastrophic drainage of a moraine-dammed lake, Khumbu Himal, Nepal: Cause and consequences. Mount Res Dev 7:91-110. https://doi.org/10.2307/3673305 
Walder JS, Costa JE (1996) Outburst floods from glacier-dammed lakes: the effect of mode of lake drainage on flood magnitude. Earth Surf Proc Land 21:701-723

Wang S, Qin D, Xiao C (2015) Moraine-dammed lake distribution and outburst flood risk in the Chinese Himalaya. J Glaciol 61(225):115-126. https://doi.org/10.3189/2015JoG14J097

Wang X, Liu S, Ding Y, Guo W, Jiang Z, Liu JS, Han Y (2012) An approach for estimating the breach probabilities of moraine-dammed lakes in the Chinese Himalayas using remote-sensing data. Nat Hazards Earth Syst Sci 12:3109-3122. https://doi.org/10.5194/nhess-12-3109-2012

Westoby MJ, Glasser NF, Brasington J, Hambrey MJ, Quincey DJ, Reynolds JM (2014) Modelling outburst floods from moraine-dammed glacial lakes. Earth-Sci Rev 134:137-159. https://doi.org/10.1016/j. earscirev.2014.03.009

Worni R, Huggel C, Stoffel M (2013) Glacial lakes in the Indian Himalayas - From an area-wide glacial lake inventory to on-site and modeling based risk assessment of critical glacial lakes. Sci Total Environ 468-469:71-84. https://doi.org/10.1016/j.scitotenv.2012.11.043

Yao X, Liu S, Sun M, Wei J, Guo W (2012) Volume calculation and analyses of the changes in morainedammed lakes in the north Himalaya: a case study of Longbasaba lake. J Glaciol 58(210):753-761. https://doi.org/10.3189/2012JoG11J048

Zhang G, Yao T, Xie H, Wang W, Yang W (2015) An inventory of glacial lakes in the Third Pole region and their changes in response to global warming. Glob Planet Change 131:148-157. https://doi. org/10.1016/j.gloplacha.2015.05.013

Ziegler AD, Cantarero SI, Wasson RJ, Srivastava P, Spalzin S, Chow WTL, Gillen J (2016) A clear and present danger: Ladakh's increasing vulnerability to flash floods and debris flows. Hydrol Process 30:4214-4223. https://doi.org/10.1002/hyp.10919

Publisher's Note Springer Nature remains neutral with regard to jurisdictional claims in published maps and institutional affiliations. 